\title{
THE ROMANIAN CRIMINAL LAW ENFORCEMENT IN TIME IN THE LIGHT OF THE CHANGES INTRODUCED BY THE NEW ROMANIAN CRIMINAL CODE
}

\author{
L. A. Lascu
}

\author{
Liviu-Alexandru Lascu \\ Law and Economics Faculty, Social Sciences Department \\ Agora University of Oradea, Oradea, Romania \\ *Correspondence: Liviu-Alexandru Lascu, 5 M. Eminescu St., Oradea, Bihor, Romania \\ E-mail: liviulascu@yahoo.com
}

\begin{abstract}
The article aims to analyze the changes introduced by the new Criminal Code in relation to the criminal law enforcement in time, mainly in order to harmonize the criminal provisions with some constitutional principles and also, for the reason of their easily application in practice.

From this perspective we can observe that the new Criminal Code has taken over the greatest part of the provisions nowadays into force and also, has eliminated those provisions in contradiction with the constitutional principles. Among the latter we can mention those provisions which provide the retroactivity of the additional punishment, education and safety measures for reasons of public interest or the provisions relating to the optional application of the most favorable criminal law in the closed cases. We may see, also, the introduction of the laws declared unconstitutional and the Ordinances of the Government among the laws which are subjects for the application of the principle of the most favorable criminal law.
\end{abstract}

Keywords: the law activity, ultra activity, non-retroactivity, the principle of legality of the punishment, the most favorable criminal law.

\section{Introduction}

1. Introductory remarks.

The adoption of a new Romanian Criminal Code in accord with the new social and political realities of Romania, a Member State of the European Union and of the Council of Europe, requiring the rule of law in a democratic state governed by constitutional principles and laws adopted in the spirit of the Constitution, has been advertised since many years ago.

After the implementation's failure of the Criminal Code adopted in 2004, the Romanian Parliament succeeded to adopt a new Romanian Criminal Code (embedded into the Law no. 286/2009), the content of which does not indicate a specific date for implementation but provides in the article 446 paragraph (3), a requirement for the Government that within 12 months of its adoption, to submit to the Parliament a draft law relating to its application. Long after this deadline, on November 12, 2012, in the Official Monitor of Romania no. 757/2012, has been published the Law no. 187/2012 surnamed the Law of applying the new Romanian Criminal Code. This latest law foresees the date when the new Criminal Code is going to enter into force, namely February 1, 2014.

It is not our purpose in this article to analyze the feasibility of this process which requires some huge transformations of Romanian judicial system within a relatively short period of time. In the other hand, without reference to how this new Criminal Code was adopted (by using the special proceeding of Romanian Government assuming its responsibility in Parliament which entailed some criticism, especially in terms of overlapping 
the powers of the executive branch over the power of legislative branch) we propose ourselves to analyze the main changes introduced by the new Criminal Code regarding the criminal law enforcement in time by taking in account the text content of the newly adopted provisions, by comparing them with those of the current Criminal Code and also, in some particular aspects, with similar provisions of the foreign legislations. We try to emphasize our opinions regarding the drafting committee's arguments for making some changes to the current provisions, whether they are more or are less motivated.

2. Some general comments on the layout of the chapter dedicated to the criminal law enforcement in time.

The first change that introduces the matter under our discussion is the reverse of the sections' order of the Chapter II, "The criminal law enforcement". It has been arranged by firstly placing the section on "The criminal law enforcement in time" and following the section on "The territorial enforcement of the criminal law". Even though only a symbolic one and not influencing the enforcement of the criminal law in its core content, this reverse of the sections' order is not totally irrelevant. It is caused by the deep changes of the geopolitical environment of the Romanian society nowadays, far away from that one existed in 1968, the year of adoption of the current Criminal Code. If at that time the legislator had considered the supremacy of the principle of territoriality in criminal law enforcement, as an expression of the policy of "independence, and non-interference in the internal affairs of another state" a very sound slogan of the Romanian communist state's leadership, the current situation is radically different. Given the fact Romania is now a E.U. Member State which means a voluntary transfer of some of its attributes of sovereignty to the supranational E.U. institutions, is, also, a party of some international treaties creating supranational authorities such as the International Criminal Court, or taking in account its involvements in some international agreements aiming the States' cooperation in order to suppress the cross-border criminality, the principle of territoriality had to be seriously adjusted. No less important in reconsidering the principle of territoriality is the fact that within the E.U. borders, the free movement of the nationals of every E.U. Member States is guaranteed and also, the current phenomenon of globalization means an increasingly degree of the people's mobility. These all above mentioned phenomena do inherently influence the phenomenon of criminality and also entail some changes which affect the absolute supremacy of the national criminal law over the territories of the states. As a result, the national authorities have to reconsider the principle of territoriality of the national criminal law as well as many other principles related to the national criminal law enforcement.

For these reasons, we conclude, the matter of the criminal law enforcement in time prevails. It's likely the reason why, the authors of the draft new Criminal Code did the reversal of these two sections. As a general conclusion, we also observe, the matter of criminal law enforcement in time under in the new Criminal Code, underwent some changes which unveils the aim of the legislator this matter to be reshaped in the light of constitutional principles like: the legality of penalties, the non-retroactivity of the criminal law, the most favorable criminal law and the separation of the state's powers.

3. The principle of criminal law's activity

Enshrined as a basic principle of the criminal law, the principle of criminal law's activity, as stipulated in the content of the Article 3, Section 1 of the new Criminal Code remains unchanged and states that "the criminal law shall be applied to all the crimes committed during the time this law is into force". This principle is nothing more than a corollary of the constitutional principle of legality of incrimination and punishments, and therefore, the legislator did not find as necessary to amend the existing rule.

Neither the existing provisions, nor the new Criminal Code provides some details about the moments the criminal law enter into or out of force, for which, we conclude the legislator makes a tacit reference to the general principles governing the matter. 
In what concerning the entry into force of a criminal law, is not to point out any new rules than those of the Article 78 of the Constitution which provides, as a general rule, the law comes into force 3 days after the date of its publication in the Official Monitor of Romania, or on a specific date provided in its content. In what regarding the going out of force of a criminal law or only of some provisions contained therein, we have to make some commentaries about the specific provisions of the new Criminal Code.

Until couple years ago, the only cases a law or some provisions of a law went out of force were determined by the legislator's actions. The first situation was where the legislator adopts a new law which revokes or amends the law in force in that moment and the second situation was in the case of so called temporary law, which provides in its content the law is going to be applied only for a specific period of time or under certain special situations.

However, according to the current reality, these two ways depicted above, proved to be insufficient and therefore another one, the judiciary way, is going to be opened by the new Criminal Code. This new way provide the possibility a law or statutory provision (not just criminal) should not be applied, although it is not repealed, amended or reached the end, if declared unconstitutional by the Constitutional Court of Romania or incompatible with the EU legislation by the Court of Justice of the European Union (CJEU). These above mentioned courts have exclusive attributes to interpret the constitutional or E.U. legislation and both of them prevail over the national criminal laws, the decisions of these courts become mandatory and therefore, every national court is obliged not to apply the criminal provision into the question. Thus, we assist to the emergence of a new way of going out of force for a criminal law.

\section{The extra-activity of the criminal law.}

Beside the mentions we made in the previous section about the principle of the criminal law's activity, it seems to be natural to mention also the exceptions to the rule of activity, i.e., the situations where a criminal law extends its effects beyond the moment it went out of force, namely, the ultra-activity of the criminal law or the situations where a law is to be applied even to the crimes committed before its entry into force, namely the retroactivity of the criminal law. In regulating these situations of extra-activity of the criminal law, as we previously mentioned, the legislator tried to circumscribe the new Criminal Code provisions, as much as possible, to the light of the constitutional principles. In what regarding the matter we refer to, the Article 15 paragraph (2) of the Constitution, summarizing the both situations of activity and extra-activity of the criminal law, states: "The law provides only for the future, excepting the cases where is to be applied the most favorable criminal law". In other words, the constitutional provision establishes the activity and the most favorable criminal law as key principles relating to the scope of the criminal law enforcement in time.

If we refer to what changes the new Criminal Code is going to introduce on these issues, as a general note, we can see a clear mention of the situations of the criminal law's extra-activity in every stage of the criminal proceedings, we also see some of the current provisions were removed as they do not comply with the constitutional principles, as well as a harmonization of the principle of the most favorable criminal law with other constitutional principles like the separation of the powers in the state or the legality of the punishment.

4.1. The enforcement of a decriminalization law.

The Article 4 of the new Criminal Code, entitled "The enforcement of the decriminalization law", takes only the content of the first paragraph of the Article 12 of the current Criminal Code, entitled "The retroactivity of the criminal law", which states that an old criminal law does not apply and all its consequences cease, where a new law decriminalizes a fact which is a crime according to the old law. The content of the paragraph 2 of the current Criminal Code stating "The new law which provides safety measures and educational measures also applies to the crimes still on the trial" was not considered as being a case where to apply the principle of the most favorable criminal law, so, it did not pass the test of constitutionality and therefore this text disappears in the new Criminal Code. 
In what regarding the above mentioned provision, there are some opinions in doctrine according to which, the safety and educational measures should not necessarily be regarded as punitive measures in their nature and that they are provided by the criminal law rather as means of protecting the public interest than as ways of coercion. Based on this concept, the current Criminal Code established that these measures should not be applied in relation to when the crime has been committed but to the time when the crime is on the trial. Thus, the intervention of the legislator by adopting these measures is nothing more than a fresh expression of the current willingness of the society ${ }^{1}$.

Even if the new regulation does not change the legal nature of these above mentioned measures, their retroactive enforcement is no more possible, because they are contrary to the constitutional principle enunciated in the Article 15 paragraph (2) of the Romanian Constitution.

\subsection{The enforcement of the most favorable criminal law.}

Established in the current Criminal Code and the Romanian Constitution, this principle of criminal law is also previewed in the new Criminal Code, with the mention, its provisions have suffered some changes.

The reason to apply this principle into an ongoing criminal proceeding is that of making a kind of social equity. Thus, if a new criminal law is more lenient than that into force at the moment the crime has been committed, then it seems to be natural to apply it even to the facts committed before its entry into force, because this new criminal law meets the new demands of the society for alleviated conditions of criminal liability, as expressed by the legislator. In the opposite situation, if the new criminal law is less favorable, then it is abnormal and against the constitutional principle of legality of the penalties for the perpetrator, who is expected to behave according to the requirements of the law in force at the moment of the crime commission, to burden some more severe conditions, as provided by the new criminal law, just because these are understood as being in accord with the current will of the society.

Known as "eclectic" or "two-dimensional", this above mentioned theory about the enforcement of the most favorable criminal law prevails nowadays in this matter of the criminal law. Its double dimension consists in the fact, on the one hand, it takes the opinions of the classical school of law relating to the ultra-activity of the criminal law, considering the subjective rights which the person has already acquired, on the other hand, it takes also the opinions of the positivist school's representatives regarding the retroactivity of the criminal law, as it represents a fresh view of the society and also a better response to the crime in question.

We can note, also, that in the new Criminal Code, this matter has been restructured in the sense, its provisions were delimitated according to the fact there is or there is not a final decision of the chamber in the trial. This separation seems to be natural, because the things the judges are demanded to do, are different in these two cases.

\subsubsection{The enforcement of the most favorable criminal law until the chamber gives a} final sentence in its judgment.

In this first situation, the judge who is demanded to apply the principle of the most favorable criminal law has to compare the provisions of the all criminal laws which were into force in the period since the crime under discussion has been committed and until the moment the final decision has been issued. Following, the judge has to asses which one provision of these laws, according to the principles of doctrine and the concrete situation of the case on the trial, meets the criteria of being the most favorable, then to apply it, accordingly. However, it

\footnotetext{
${ }^{1}$ See, V. Dobrinoiu, I. Pascu, I. Molnar, G. Nistoreanu, A. Boroi, Drept penal, Partea generală, "Europa Nova" Publishing House, Bucharest, 1997, p. 75.

${ }^{2}$ See, M. Basarab, V. Paşca, G. Mateuț, C. Butiuc, Codul penal comentat. Vol. I., Partea generală, "Hamangiu" Publishing House, Bucharest, 2007, p. 52.
} 
should be mentioned that neither the present nor the new regulations have established some legal criteria according to which, the judge may asses the most favorable law. Therefore, the judge is called to determine, according to the concrete situation, the elements that qualify a law as being more favorable than others, but a combination of some provisions of those laws in the aim of creating a more favorable situation for the accused, is not allowed ${ }^{3}$.

An innovatory provision of the new Criminal Code in this matter is that provided in the Article 5 paragraph (2) which explicitly state that among the laws, taken into account when making the application of the most favorable criminal law, must be found also the laws or part of laws which have been found unconstitutional, as well as the Government's Emergency Ordinances (G.E.O.), regardless the fact they have been later approved by the Parliament, amended, improved or rejected, provided that they had been into force in a specific period of time, since the crime had been committed until to the final judgment of the case. The reason for introducing this provision is obvious. The mentioned above laws and G.E.O., even if currently they are fully or partially out of work, they were in the past time into force and applied in some concrete situations, during the relevant period of time (i.e. since the crime had been committed to the final judgment of the case). Consequently, if compared with other criminal laws which were enforced within the same period of time and appear as being more favorable, then, it is natural these unconstitutional laws or G.E.O.s to be considered as "criminal laws" within the meaning of the Article 5, paragraph (1) of the new Criminal Code.

Another change in the new Criminal Code, belonging also to this chapter is that removing the content of Article 13 paragraph (2) of the current Criminal Code, relating to the regime of the complementary penalties. In the current regulatory regime has been set up a rule in what concerning the application of the complementary penalties, in the sense the new law will be always applied. The explanation of the Romanian legislator adopting this type of regulation lies in the influences of the positivist law school over the Romanian criminal doctrine at the time the current Criminal Code had been adopted, that is, in the matter of the complementary penalties, a new law always reflects the current needs of the social defense in a better way than the previews laws ${ }^{4}$. The legislator has chosen this regulatory pathway most probably because the complementary penalties are being imposed largely in the aim of protecting the public interest. The fact that the legislator gave up this provision in the new Criminal Code appears as being natural since it contravenes the constitutional principle of non-retroactivity of the law. As the only one exception is allowed where is to be applied the principle of the most favorable law in criminal matters and the hypothesis of applying it to the regime of complementary penalties can not be excluded, makes us to conclude that the provision to which we refer of the current Criminal Code is obviously unconstitutional and this is the reason of not including it among the provisions of the new Criminal Code.

4.2.2. The enforcement of the most favorable criminal law after the final sentence in the case is done.

Unlike in the situation presented in the previous section, the judge in the position to apply the principle of the most favorable criminal law to a case definitively tried has a different mission. The sentence of those cases has already established, the principal penalty as well as the complementary penalty or safety or education measures, where appropriate. The judge is required, then, to apply the most favorable criminal law solely in those cases where the new criminal law contains some lenient provisions regarding the limits of the punishments or the measures above mentioned. The enforcement of the most favorable criminal law appears to be justified even in some situations where a great deal of punishment or measures has already been done.

\footnotetext{
${ }^{3}$ The rule of "lex tertia exclusion" supposes that a judge cannot combine two or more favorable provisions belonging to distinct laws, in order to create a new one, as the most favorable. This is because the judge cannot substitute the legislator. See V. Paşca in M. Basarab, V. Paşca, G. Mateuț, C. Butiuc, Codul penal comentat. Vol. I, Partea generală, "Hamangiu" Publishing House, Bucharest, 2007, p. 54.

${ }^{4}$ Ibidem, p. 58.
} 
The new Criminal Code has taken over some of the current regulations relating the situations where the new law must be compulsorily applied, namely those of the Article 14 paragraph (1)-(3). We can see also, those regulations relating to additional penalties, education and safety measures provided in the Article 14 paragraph (4) of the current Criminal Code have been modified. The provisions of the Article 15 regarding the situations where the application of the most favorable criminal law is optional, does not appear in the new regulation. Further, we are going to examine in turn each of these cases.

With respect to the principal penalties (i.e. the life detention, imprisonment and fine), the regulation remains unchanged, meaning that, if the sentence of imprisonment or fine is greater than the maximum level set by the new criminal law for the crime under discussion, the penalty must be reduced to this maximum level of the new law and whether the new law provides for a lenient kind of penalty, like some years of imprisonment instead of life detention or or a fine instead of imprisonment, then it must replace it with the maximum of the penalty provided in the new law. If being previewed a fine in the new law, taking in account the imprisonment already done, it can be removed in whole or in part. These changes of punishment are required not only in the aim of applying the most favorable criminal law but also in the aim of complying with the principle of the legality of the penalties. If those persons convicted under the old criminal law had to burden a different kind of punishment or in some limits greater than those required by the new law, than we would be in a situation of a violation of this constitutional principle.

In what regarding the current provisions of the Article 14 paragraph (3), relating to the additional penalties, education and safety measures we can observe that their modification is justified since they allow the new criminal law to be retroactively enforced, even if it contains some provisions more stringent than those of the old law. As in the cases mentioned above, the regulation currently in force was designed so, at that time, for reasons of public interest. Currently, it would be contrary to the constitutional principle which allows a retroactive enforcement of a criminal law only if it's more favorable.

A substantive change introduced by the new Criminal Code is the fact, among its provisions are no longer previewed that regulating "the optional enforcement of the most favorable criminal law in the cases the punishment is already established by a final sentence" as provided in the Article 15 of the current Criminal Code. From the explanations of the Government ${ }^{5}$, which accompanied the draft new Criminal Code during the debates in Parliament, we can conclude that the reason to abandon the regulation in question is the application of the principle of separation of the powers in state, explicitly enshrined in the Constitution. Based on this, it was considered that between res judicata as an attribute of the judiciary branch and the principle of the most favorable criminal law as a result of adopting a new criminal law by the legislative power, must be a balance. The legislator's aim was a judicial sentence to be subject of modification by the legislative branch, only in some exceptional circumstances. Specifically, if a criminal penalty was established by a final sentence, then it will be rightly changed by the new law, according to the Article 6 of the new Criminal Code, only if the nature differs or the limit of the penalty exceeds from those of the new law. The reason is obvious, namely, to avoid a conflict with another constitutional principle, namely the legality of the penalties. Otherwise, res judicata can not be changed by the legislative or executive branch.

\section{The temporary criminal law enforcement.}

The provisions relating to this matter can be found in the both criminal codes. The novelty is the fact, beside the provision of the current Criminal Code in Article 16, namely "the temporary criminal law must be applied to the crimes committed while it was in force, even if the act not been prosecuted or tried at that time", in the new Criminal Code, the

\footnotetext{
${ }^{5}$ See, *** Noul Cod Penal. Expunere de motive, "Hamangiu" Publishing House, Bucharest, 2009, p. 6.
} 
legislator has added a definition of the term "temporary criminal law". Thus the Article 7, after the paragraph (1) which integrally took over the content of the provision mentioned above, states in the paragraph (2) that the temporary criminal law is that "...which provides the moment of its out of force or whose enforcement is limited by the temporary nature of the situation which entailed its adoption". The definition has a beneficial effect in terms of clarifying the concept of temporary criminal law but otherwise, it does nothing but takes the definition already existing in the Romanian criminal doctrine.

Nevertheless, a problem in question still remains unclear after the adoption of the new Criminal Code, namely that concerning the ultra-activity of the temporary criminal law, because this temporary criminal law will be replaced by a new criminal law, most probably, a more favorable one. The authors in Romanian criminal doctrine support two contrary opinions.

On one side are those who argue that the temporary criminal law will be applied even after the period it was in force, for the acts committed during that period and still not definitively tried. The reason would be that it's the express will of the legislator in this respect since it explicitly regulated so ${ }^{6}$. Otherwise, given the limited and not very long period of time during which it becomes effective, this temporary law will be deprived of efficiency in a significant manner even more because is to be expected that most of these acts will be prosecuted and tried beyond the expiry of the temporary law.

On the other side are those who argue that the temporary criminal law cannot be an exception to the general rule of the enforcement of the principle of the most favorable criminal law, as it has been expressly provided in the Constitution, and prevails over any provision of the Criminal Code. They say also, if not being provided an explicit exception of the enforcement of this principle in what concerning the temporary criminal law, a different interpretation would cause major disruptions in practice ${ }^{7}$.

Although the first view can be seen as a correct argument in the need for an effective enforcement of the temporary criminal law in a very special period, we believe that given the legal force of the principle which allows a more favorable criminal law to be enforced retroactively is likely to seriously limit the ultra-activity of the temporary criminal law.

\section{Conclusions}

The changes introduced by the new Criminal Code relating to the matter of the criminal law enforcement in time, in the greatest part of them, were expected since long time ago, for various reasons. Firstly, the enforcement of a criminal code, older than 40 years, who survived a radical change of political regime, was becoming more difficult to be enforced in the same time with a new Constitution adopted in 1991 which follows the model of the democratic states and which provides guarantees, rights and freedoms for the citizens. Even if not strictly in the matter discussed above, the provisions of the current Criminal Code clashed several times the constitutional principles and therefore, the Constitutional Court was asked to adjust a great part of these provisions. Over the time, the number of these unconstitutional provisions became greater and greater, and it has created the impression of a "patched building which does not deserve to be renewed but to be entirely rebuilt".

If the legislature has succeeded to create a modern and efficient legal framework in the matter to which we refer, is too early to say. What we see is that the mechanism of harmonization of each criminal provision with the constitutional principles did work efficiently and therefore, in the future, as long as this Constitution remains unchanged in what

\footnotetext{
${ }^{6}$ See, T. Vasiliu, G. Antoniu, Ş. Daneş, Gh. Dărângă, D. Lucinescu, V. Papadopol, D. Pavel, D. Popescu, V. Rămureanu, Codul penal, comentat şi adnotat, Partea generală, "Editura Ştiințifică” Publishing House, Bucharest, 1972, p. 83.

${ }^{7}$ See, M. Basarab, Drept penal. Partea generală, vol. I \& II, "Lumina Lex" Publishing House, Bucharest, 1995, p. 61 .
} 
regarding the principles above mentioned, we believe that the exceptions of unconstitutionality with respect to the criminal provisions will be invoked to a lesser extent.

Another category of changes were determined by the socio-political realities that characterize Romanian society nowadays. We refer to the fact Romania is a Member State of the European Union, which requires certain standards in the national legislation and also to be harmonized with those belonging to other Member States.

On the other hand, as a State Member of the Council of Europe which requires certain standards in the administration of justice, implicitly recognizing the jurisdiction of the European Court of Human Rights (ECHR) and the recommendations of this court, the Romanian state had to adapt its criminal legislation including the provisions of the new Criminal Code. There were not just a few the convictions of the Romanian state by ECHR's decisions caused by certain criminal provisions which violated the Human Rights Convention and consequently, the legislator had been enforced to adopt the new Criminal Code in accordance with these ECHR's requirements.

As a final conclusion we say that essentially in the near future for the new Criminal Code is to enter into force, together with some procedural provisions, highly correlated, as to allow a proper enforcement. It is quite possible that some of its provisions are still not appropriate from a constitutional perspective or in relation with the requirements of the European standards but all these troubles can be recovered. Its entering into force, even though with some challenged provisions, will be the small evil if comparing with the evil burden by the Criminal Code adopted in 2004 which did not ever enter into force.

\section{Bibliography} 2009;

*** Noul Cod Penal. Expunere de motive, "Hamangiu" Publishing House, Bucharest,

M. Basarab, V. Paşca, G. Mateuț, C. Butiuc, Codul penal comentat. Vol. I., Partea generală, "Hamangiu" Publishing House, Bucharest, 2007;

V. Dobrinoiu, I. Pascu, I. Molnar, G. Nistoreanu, A. Boroi, Drept penal, Partea generală, "Europa Nova" Publishing House, Bucharest, 1997;

M. Basarab, Drept penal. Partea generală, vol. I \& II, "Lumina Lex" Publishing House, Bucharest, 1995;

T. Vasiliu, G. Antoniu, Ş. Daneş, Gh. Dărângă, D. Lucinescu, V. Papadopol, D. Pavel, D. Popescu, V. Rămureanu, Codul penal, comentat şi adnotat, Partea generală, "Editura Ştiinţifică” Publishing House, Bucharest, 1972. 